\title{
PENGARUH DOSIS ARANG SEKAM PADI DAN PUPUK KANDANG SAPI TERHADAP PERTUMBUHAN DAN PRODUKSI TANAMAN JAGUNG HIBRIDA (Zea mays L.) PADA SALINITAS TANAH
}

\author{
THE EFFECT OF RICE HUSK CHARCOAL DOSAGES AND COW FERTILIZER ON \\ GROWTH AND PRODUCTION OF HYBRID CORN (Zea mays L.) IN SOIL SALINITY
}

\author{
Intan Dharmasika*, Susilo Budiyanto, Florentina Kusmiyati \\ Program Studi S1 Agroekoteknologi, Departemen Pertanian, Fakultas Peternakan dan \\ Pertanian, Universitas Diponegoro, Tembalang, Semarang 50275 - Indonesia \\ *Corresponding Author: intandharmasika17@gmail.com
}

Diterima: 5 Nopember 2019, Direvisi: 21 Nop 2019, Disetujui: 26 Desember 2019

\begin{abstract}
ABSTRAK
Penelitian ini dilakukan akibat kebutuhan jagung di Indonesia dan kegiatan impor jagung yang terus meningkat sehingga perlu adanya perluasan area budidaya dengan memanfaatkan lahan marginal sebagai lahan budidaya dan memperbaiki kondisi lahan agar tanaman jagung mampu tumbuh. Penelitian ini bertujuan untuk mengkaji pengaruh pemberian arang sekam padi dan pupuk kandang sapi terhadap pertumbuhan dan produksi tanaman jagung hibrida pada tanah salin. Penelitian dilaksanakan dari bulan November 2018 s/d Februari 2019 di Lahan Pertanian Desa Dresi Wetan, Kecamatan Kaliori, Kabupaten Rembang, Jawa Tengah. Penelitian menggunakan Rancangan Acak Kelompok (RAK) pola faktorial 3 x 3 dengan 3 ulangan. Faktor pertama, dosis arang sekam padi (0 ton/ha, 4 ton/ha dan 6 ton/ha). Faktor kedua, dosis pupuk kandang sapi (0 ton/ha, 7,5 ton/ha dan 15 ton/ha). Data dianalisis ragam (ANOVA) dan dilanjutkan dengan uji jarak berganda Duncan (DMRT) pada taraf 5\%. Variabel yang diamati adalah tinggi tanaman; jumlah daun; jumlah baris biji per tongkol; bobot jagung pipilan; rendemen dan daya hantar listrik tanah. Hasil penelitian menunjukkan bahwa interaksi pemberian arang sekam padi dan pupuk kandang sapi berpengaruh nyata terhadap jumlah baris biji per tongkol; bobot jagung pipilan; rendemen dan nilai daya hantar listrik tanah. Aplikasi arang sekam padi 6 ton/ha dan pupuk kandang sapi 15 ton/ha menghasilkan pertumbuhan dan produksi lebih tinggi. Tinggi tanaman, jumlah daun dan bobot pipilan jagung masih dibawah potensial genetik tanaman jagung hibrida.
\end{abstract}

Kata kunci : Arang Sekam Padi, Pupuk Kandang Sapi, Pertumbuhan, Produksi, Zea mays L.

\section{ABSTRACT}

This research was carrie out due to the need for corn in Indonesia and corn import activities that continue to increase so it is necessary to expand the cultivation area by utilizing marginal land as cultivated land and improve land conditions so that corn plants can grow. This research aim was to examine the effect of rice husk charcoal and cow manure on growth and production of maize at saline soil. The research was conducted from November 2018 to February 2019 in the Agricultural Land of Dresi Wetan Village, Kaliori District, Rembang Regency, Central Java. The research used a factorial randomized block design (RBD) $3 \times 3$ with 3 replications. First factor was dosage of rice husk charcoal ( 0 ton/ha, 4 ton/ha and 6 ton/ha). The second factor was dosage of cow manure (0 ton/ha, 7,5 ton/ha and 15 ton/ha). Data were analyzed by analysis of variance (ANOVA) and continued with Duncan's Multiple Range Test (DMRT) at 5\% level. Variables observed were plant height; number of leaves; number of seed rows per cob; weight of

Pengaruh Dosis Arang Sekam Padi dan Pupuk Kandang Sapi Terhadap Pertumbuhan dan Produksi Tanaman 195 Jagung Hibrida (Zea mays L.) Pada Salinitas Tanah - Intan Dharmasika, Susilo Budiyanto, Florentina Kusmiyati 
corn; yield and soil electrical conductivity. The results showed that the interaction of providing rice husk charcoal and cow manure significantly affected number of seed rows per cob, weight of corn; yield and soil electrical conductivity. The application of 6 ton/ha of rice husk charcoal and 15 ton/ha of cow manure produced highest growth and production. Plant height, number of leaves and weight of corn was still below the genetic potential of hybrid maize.

Keywords : Rice Husk Charcoal, Cow Manure, Growth, Yield, Zea mays L.

\section{PENDAHULUAN}

Tanaman jagung merupakan tanaman pangan yang dibudidayakan di Indonesia karena dapat digunakan sebagai pengganti beras bagi sebagian penduduk Indonesia. Kebutuhan jagung tiap tahun mengalami peningkatan sebesar $10-15$ persen, sehingga impor jagung meningkat tiap tahunnya. Kementan (2018) menyatakan bahwa tahun 2017 impor jagung Indonesia telah mencapai 1,6 juta ton. Upaya untuk memenuhi kebutuhan jagung dapat dilakukan dengan perbaikan sistem budidaya agar produksi meningkat dan perluasan areal tanam. Perluasan areal tanam dapat dilakukan dengan memanfaatkan tanah-tanah marginal salah satunya adalah tanah salin. Permasalahan tanah salin adalah nilai daya hantar listrik tanah dan kadar garamnya tinggi sehingga akan menyebabkan terjadinya cekaman lingkungan. Kondisi ini akan menyebabkan tingkat kesuburan tanah menurun yang berdampak pada produktivitas lahan pertanian menurun.

Kondisi tanah di Kabupaten Rembang sebagian besar merupakan tanah salin, akibat kandungan garam terlarut tinggi sehingga tanaman mengalami cekaman salinitas tanah. Upaya dalam menangani cekaman salinitas tanah pada tanaman jagung dapat dilakukan dengan penambahan arang sekam padi untuk meningkatkan ketahanan tanaman dan penambahan pupuk kandang sapi untuk menurunkan konsentrasi natrium pada tanah salin.
Arang sekam padi mengandung unsur silika kadar tinggi yaitu $87-97 \%$ yang dapat meningkatkan ketahanan tanaman terhadap ketidakseimbangan unsur hara, menguatkan batang sehingga tanaman tahan rebah, mengurangi cekaman abiotik maupun biotik sehingga dapat memperkuat jaringan (Purwaningsih, 2009). Unsur silika yang terakumulasi pada daun akan menjaga daun tetap tegak sehingga membantu penangkapan cahaya matahari untuk fotosintesis dan translokasi $\mathrm{CO}_{2}$ dan $\mathrm{P}$ ke malai (Pikukuh et al., 2015). Pemberian arang sekam padi sebesar 5 ton/ha sebagai pembenah tanah dapat memberikan pengaruh terhadap sifat kimia tanah, pertumbuhan dan produksi tanaman (Onggo et al., 2017). Pupuk kandang sapi dapat meningkatkan kandungan hara, menurunkan $\mathrm{pH}$ tanah, meningkatkan daya ikat air dalam tanah sebagai pelarut nutrisi bagi petumbuhan tanaman (Muharam, 2017). Pupuk kandang sapi mampu mencukupi kebutuhan hara tanaman sehingga dapat menyelesaikan siklus hidupnya lebih cepat, namun pemberian pupuk dilakukan sesuai kebutuhan tanaman agar tanaman tidak kelebihan ataupun kekurangan hara (Amiruddin et al., 2017).

Penelitian ini bertujuan untuk mengkaji pengaruh pemberian arang sekam padi dan pupuk kandang sapi terhadap pertumbuhan dan produksi tanaman jagung pada tanah salin. 


\section{BAHAN DAN METODE}

Penelitian ini dilaksanakan dari bulan November 2018 sampai dengan Februari 2019 di Lahan Pertanian Desa Dresi Wetan, Kecamatan Kaliori, Kabupaten Rembang, Provinsi Jawa Tengah. Kabupaten Rembang secara geografis terletak di 6030' - 706' LS $111000^{\prime}-111030$ ' BT dengan ketinggian $10-70 \mathrm{~m}$ di atas permukaan laut.

Bahan yang digunakan pada penelitian ini adalah lahan salin dengan kadar Electrical Conductivity $=\mathrm{EC}>4$ $\mathrm{dS} / \mathrm{m}$ dan kadar Natrium 0,34 me/100 gram, pupuk kandang sapi, benih tanaman jagung Var. BISI 2, air dan lahan dengan luas petak $4,5 \mathrm{~m} \times 3,5 \mathrm{~m}$ sebanyak 27 petak. Alat yang digunakan pada penelitian ini adalah traktor, cangkul, tongkat tugal, meteran, tali rafia, tongkat kayu dan bambu, timbangan digital kapasitas $50 \mathrm{~kg}$, ember, sabit, karung kapasitas, TDS meter, alat tulis dan kamera.

Penelitian menggunakan Rancangan Acak Kelompok (RAK) pola faktorial 3 x 3 dengan 3 kali ulangan. Faktor pertama adalah dosis arang sekam padi dengan 3 taraf perlakuan yaitu ( 0 ton/ha; 4 ton/ha dan 6 ton/ha). Faktor kedua adalah dosis pupuk kandang sapi dengan 3 taraf perlakuan yaitu (0 ton/ha; 7,5 ton/ha dan 15 ton/ha).

Penelitian dilakukan dalam beberapa tahap, yaitu analisis tanah, sekam dan pupuk; persiapan lahan; penanaman; pemupukan; pemeliharaan; pemanenan dan pengamatan. Tahap pertama, yaitu analisis tanah, arang sekam padi dan pupuk kandang sapi dengan mengambil sampel dan dianalisis di Laboratorium Balai Lingkungan dan Tanaman. Tahap kedua, yaitu persiapan lahan tanam meliputi pengolahan tanah dengan membalik tanah dengan traktor dan cangkul. Tahap ketiga, yaitu penanaman benih jagung dilakukan bersamaan pemberian arang sekam padi dan pupuk kandang sapi dengan menanam 2 benih pada tiap lubang sedalam $2-3 \mathrm{~cm}$ dengan jarak tanam $80 \mathrm{~cm} \times 20 \mathrm{~cm}$. Tahap keempat, yaitu pemupukan NPK rekomendasi dengan dosis $150 \mathrm{~kg}$ urea/Ha yang diberikan 2 kali setelah 1 minggu setelah tanam bersamaan dengan penyulaman dan 3 minggu setelah tanam, $100 \mathrm{~kg} \mathrm{TSP} / \mathrm{ha}$ dan $150 \mathrm{~kg} \mathrm{KCl} / \mathrm{ha}$ diberikan 35 hari setelah tanam. Tahap kelima, yaitu pemeliharaan meliputi menyiram dengan alat gembor, pengendalian organisme penggangu tanaman dengan cara menyiangi gulma pada lahan tanam, dan membuang serangga atau hama secara mekanik. Tahap keenam, yaitu pemanenan dilaku-kan 100 HST dan telah menghasilkan jagung yang sudah siap panen secara serempak satu kali, dengan cara memetik tongkol jagung. Variabel yang diamati yaitu tinggi tanaman, jumlah daun, jumlah baris biji per tongkol, bobot jagung pipilan, rendemen dari hasil bagi bobot pipilan dan berat tongkol serta nilai daya hantar listrik tanah dengan cara melarutkan sampel tanah didalam akuades pada perbandingan 1 gram sampel tanah dan $10 \mathrm{ml}$ akuades yang diukur menggunakan alat TDS meter (Azhari et al., 2017) dapat dilihat pada Gambar 1. 


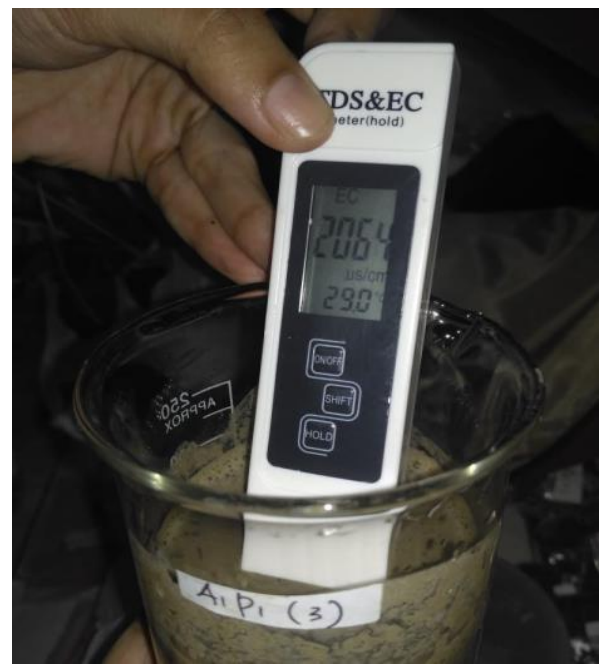

Gambar 1.

Pengukuran EC Tanah

Pengolahan data dilakukan dengan cara dianalisis ragam (ANOVA) untuk melihat pengaruh perlakuan dan kemudian dilanjutkan dengan uji jarak berganda Duncan (Duncan's Multiple Range Test) pada taraf $5 \%$ untuk melihat perbedaan antar perlakuan.

\section{HASIL DAN PEMBAHASAN \\ Salinitas Tanah}

Hasil analisis ragam memperlihatkan bahwa perlakuan arang sekam padi, pupuk kandang sapi dan interaksi antara arang sekam padi dengan pupuk kandang sapi berpengaruh nyata terhadap nilai daya hantar listrik tanah. Hasil pengamatan nilai daya hantar listrik tanah pada berbagai perlakuan pemberian arang sekam padi dan pemberian pupuk kandang sapi serta hasil uji jarak berganda disajikan pada Tabel 1.

Tabel 1.

Nilai daya hantar listrik tanah (dS/m) akibat berbagai dosis arang sekam padi dan pupuk kandang sapi

\begin{tabular}{|c|c|c|c|c|}
\hline \multirow{2}{*}{$\begin{array}{c}\text { Dosis Arang Sekam } \\
\text { Padi }\end{array}$} & \multicolumn{3}{|c|}{ Dosis Pupuk Kandang Sapi } & \multirow{2}{*}{ Rata-rata } \\
\hline & 0 ton/ha & 7,5 ton/ha & 15 ton/ha & \\
\hline \multicolumn{5}{|c|}{.........................(d) } \\
\hline 0 ton/ha & $4,40^{\mathrm{a}}$ & $3,31^{\mathrm{b}}$ & $2,71^{\mathrm{c}}$ & $3,47^{\mathrm{a}}$ \\
\hline 4 ton/ha & $2,56^{\mathrm{cd}}$ & $2,68^{c}$ & $2,42^{\mathrm{cd}}$ & $2,55^{\mathrm{b}}$ \\
\hline 6 ton/ha & $2,05^{\mathrm{d}}$ & $2,08^{\mathrm{d}}$ & $2,10^{\mathrm{d}}$ & $2,07^{\mathrm{b}}$ \\
\hline Rata-rata & $3,02^{\mathrm{a}}$ & $2,69^{\mathrm{ab}}$ & $2,39^{\mathrm{b}}$ & \\
\hline
\end{tabular}

Superskrip yang berbeda pada baris dan kolom yang sama serta matriks interaksi menunjukkan perbedaan nyata pada taraf $\alpha=5 \%$

Tabel 1. menunjukkan bahwa nilai daya hantar listrik tanah menghasilkan perbedaan pada perlakuan tanpa pemberian pupuk kandang sapi 
dengan arang sekam padi 6 ton/ha (2,05 $\mathrm{dS} / \mathrm{m}$ ) lebih rendah dibandingkan tanpa arang sekam padi dan tanpa pupuk kandang sapi (4,40 dS/m).

Hal tersebut menunjukkan bahwa dengan penambahan arang sekam padi dan pupuk kandang sapi secara tunggal maupun kombinasi mampu menurunkan daya hantar listrik tanah melalui unsurunsur pembentuk dalam bentuk ion (kation atau anion) yang dapat mengikat $\mathrm{Na}^{+}$dan $\mathrm{Cl}^{-}$. Ion tersebut berasal dari proses fisika, kimia atau biologi sehingga kadar kation dalam tanah lebih tinggi dibanding kadar unsur $\mathrm{Na}^{+}$, mengakibatkan terjadinya peningkatan akumulasi silika serta penurunan daya hantar listrik dalam tanah. Pendapat tersebut sesuai dengan pendapat Subowo (2010) yang menyatakan bahwa efisiensi penggunaan bahan organik sebagai pupuk untuk meningkatkan kesuburan melalui proses fisiko-kimia selama dekomposisi bahan organik unsur hara $\mathrm{Ca}, \mathrm{Mg}$, dan $\mathrm{K}$ terus dilepaskan sebagai kation bebas.
Arang sekam padi dan pupuk kandang sapi yang terakumulasi mampu menurunkan kation dan endapan garam. Pendapat tersebut sesuai dengan pendapat Nurahmi (2010) bahwa keberadaan banyak sedikitnya jumlah bahan organik tanah menyebabkan kondisi kimia tanah menjadi faktor pembatas proses pertukaran kation.

\section{Tinggi Tanaman}

Hasil analisis ragam memperlihatkan bahwa perlakuan arang sekam padi dan pupuk kandang sapi berpengaruh nyata terhadap tinggi tanaman, sedangkan interaksi arang sekam padi dengan pupuk kandang sapi tidak berpengaruh nyata terhadap tinggi tanaman jagung. Hasil pengamatan tinggi tanaman jagung akibat perlakuan pemberian dosis arang sekam padi dan pemberian dosis pupuk kandang sapi serta hasil uji jarak berganda disajikan pada Tabel 2.

Tabel 2.

Tinggi tanaman jagung pada 4 Minggu Setelah Tanam (MST) akibat berbagai dosis arang sekam padi dan pupuk kandang sapi

\begin{tabular}{|c|c|c|c|c|}
\hline \multirow{2}{*}{$\begin{array}{c}\text { Dosis Arang Sekam } \\
\text { Padi }\end{array}$} & \multicolumn{3}{|c|}{ Dosis Pupuk Kandang Sapi } & \multirow{2}{*}{ Rata-rata } \\
\hline & 0 ton/ha & 7,5 ton/ha & 15 ton/ha & \\
\hline \multicolumn{5}{|c|}{...........................(cm) } \\
\hline 0 ton/ha & 11,56 & 15,59 & 27,44 & $18,20^{\mathrm{b}}$ \\
\hline 4 ton/ha & 25,26 & 30,03 & 33,60 & $29,63^{\mathrm{a}}$ \\
\hline 6 ton/ha & 31,04 & 30,56 & 40,29 & $33,97^{\mathrm{a}}$ \\
\hline Rata-rata & $22,62^{c}$ & $25,39^{\mathrm{b}}$ & $33,78^{\mathrm{a}}$ & \\
\hline
\end{tabular}

Superskrip yang berbeda pada baris dan kolom yang sama menunjukkan perbedaan nyata pada taraf $\alpha=5 \%$

Tabel 2. menunjukkan bahwa penambahan dosis arang sekam padi dan pupuk kandang sapi yang meningkat mampu meningkatkan tinggi tanaman jagung. Hal ini dikarenakan penambahan arang sekam padi mengandung unsur silika untuk menjaga kondisi lingkungan dengan memperbaiki sifat fisik tanah salin menjadi lebih gembur dan daya ikat air yang tinggi sehingga pertumbuhan vegetatif tanaman jagung dan proses distribusi fotosintat pada organ vegetatif jagung menjadi lebih baik. Menurut Amrullah et al. (2014) yang menyatakan bahwa kandungan unsur silika ( $\mathrm{Si}$ ) dapat memperbaiki sifat fisik tanaman apabila 
unsur silika dalam tanah kurang dari 5 persen maka tegak tanaman tidak kuat dan mudah roboh. Penambahan pupuk kandang sapi mampu menyediakan unsur hara nitrogen, posfor dan kalium untuk proses pertukaran ion bebas kation di dalam tanah salin dan dibantu oleh mikroorganisme pengurai (dekomposer) untuk merombak bahan organik pupuk kandang sapi sehingga endapan garam natrium tanah akan menurun karena ion maupun senyawa beracun yang terkandung dalam tanah salin akan diuraikan oleh mikroorganisme menjadi ion bebas dan memperbaiki pembelahan sel dan pembesaran sel pada batang dan organ vegetatif lain pada tanaman jagung. Pendapat tersebut sesuai dengan pernyataan Nurahmi (2010) bahwa sedikit dan banyaknya jumlah bahan organik tanah menyebabkan kondisi kimia tanah menjadi faktor pembatas proses pertukaran kation.

Tinggi tanaman jagung semakin meningkat pada peningkatan dosis arang sekam padi maupun pupuk kandang sapi yang diberikan. Kombinasi arang sekam padi 6 ton/ha dengan pupuk kandang sapi 15 ton/ha menghasilkan tinggi tanaman $40,29 \mathrm{~cm}$ lebih rendah dibandingkan dengan potensial genetik dari tanaman jagung hibrida yaitu $\pm 232 \mathrm{~cm}$ (Balitsereal, 2012).

\section{Jumlah daun}

Hasil analisis ragam memperlihatkan bahwa perlakuan arang sekam padi dan pupuk kandang sapi berpengaruh nyata terhadap jumlah daun jagung, sedangkan interaksi arang sekam padi dengan pupuk kandang sapi tidak berpengaruh nyata terhadap jumlah daun jagung. Hasil pengamatan jumlah daun jagung pada berbagai perlakuan pemberian arang sekam padi dan pupuk kandang sapi serta hasil uji jarak berganda disajikan pada Tabel 3.

Tabel 3. menunjukkan bahwa penambahan dosis arang sekam padi dan pupuk kandang sapi yang meningkat mampu meningkatkan jumlah daun tanaman jagung yang bervariasi. Hal ini dikarenakan arang sekam padi mengandung unsur silika (Si) mampu memperbaiki proses pertukaran hasil fotosintesis yang terjadi pada organ daun tanaman sehingga memungkinkan meningkatkan jumlah daun serta arang sekam padi dapat memperbaiki sifat fisik tanah yang mampu meningkatkan ketersediaan unsur hara makro untuk kesuburan tanah seperti nitrogen, posfor dan kalium pada tanah salin.

Tabel 3.

Jumlah daun jagung (helai) akibat pemberian arang sekam padi dan pupuk kandang sapi

\begin{tabular}{|c|c|c|c|c|}
\hline \multirow{2}{*}{$\begin{array}{c}\text { Dosis Arang Sekam } \\
\text { Padi }\end{array}$} & \multicolumn{3}{|c|}{ Dosis Pupuk Kandang Sapi } & \multirow{2}{*}{ Rata-rata } \\
\hline & 0 ton/ha & 7,5 ton/ha & 15 ton/ha & \\
\hline \multicolumn{5}{|c|}{........................(helai) } \\
\hline 0 ton/ha & 3,28 & 3,94 & 4,84 & $4,02^{c}$ \\
\hline 4 ton/ha & 5,13 & 4,85 & 5,33 & $5,10^{\mathrm{b}}$ \\
\hline 6 ton/ha & 5,02 & 5,85 & 7,47 & $6,11^{\mathrm{a}}$ \\
\hline Rata-rata & $4,47^{\mathrm{b}}$ & $4,88^{b}$ & $5,88^{\mathrm{a}}$ & \\
\hline
\end{tabular}

Superskrip yang berbeda pada baris dan kolom yang sama menunjukkan perbedaan nyata pada taraf $\alpha=5 \%$

Menurut Zulputra, et al. (2014) yang menyatakan bahwa tanaman yang diberikan tambahan silika mempunyai potensi memperbaiki distribusi fotosintat 
sehingga lebih diarahkan pada pertumbuhan daun dibandingkan dengan pertumbuhan organ lainnya. Pemberian pupuk kandang sapi dapat meningkatkan dekomposisi di dalam tanah salin serta mampu memperbaiki struktur tanah menjadi lebih gembur sehingga struktur tanah salin baik untuk akar tanaman dalam proses penyerapan unsur hara serta pertukaran ion kation di dalam tanah untuk didistribusikan ke seluruh bagian tanaman terutama dalam proses fotosintesis di organ daun. Pendapat tersebut sesuai dengan Asroh (2010) yang menyatakan bahwa pupuk kandang dapat memperbaiki sifat fisik tanah menjadi gembur dan lepas sehingga aerasi dan porositas tanah menjadi lebih baik serta mudah ditembus akar tanaman untuk mencukupi kebutuhan unsur hara pada masa pertumbuhan vegetatif tanaman.

Jumlah daun jagung pada perlakuan arang sekam padi 6 ton/ha dengan pupuk kandang sapi 15 ton/ha menghasilkan jumlah daun 7,47 helai lebih rendah dibandingkan dengan potensial genetik dari tanaman jagung hibrida yaitu $12-16$ helai per tanaman (Balitsereal, 2012) dan beberapa helai daun masih terdeteksi terkena toksisitas seperti terdapat bercak daun berwarna cokelat kekuningan.

\section{Jumlah Baris biji}

Hasil analisis ragam memperlihatkan bahwa perlakuan arang sekam padi, pupuk kandang sapi dan interaksi antara arang sekam padi dan pupuk kandang sapi berpengaruh nyata pada jumlah baris biji jagung. Hasil pengamatan jumlah baris biji jagung pada berbagai perlakuan pemberian arang sekam padi dan pemberian pupuk kandang sapi serta uji jarak berganda disajikan pada Tabel 4.

Tabel 4.

Jumlah baris biji per tongkol (baris) akibat berbagai dosis arang sekam padi dan pupuk kandang sapi

\begin{tabular}{|c|c|c|c|c|}
\hline \multirow{2}{*}{$\begin{array}{c}\text { Dosis Arang Sekam } \\
\text { Padi }\end{array}$} & \multicolumn{3}{|c|}{ Dosis Pupuk Kandang Sapi } & \multirow{2}{*}{ Rata-rata } \\
\hline & 0 ton/ha & 7,5 ton/ha & 15 ton/ha & \\
\hline \multicolumn{5}{|c|}{ 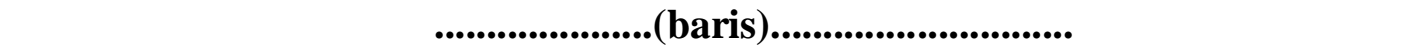 } \\
\hline 0 ton/ha & $7,70^{\mathrm{e}}$ & $10,89^{d}$ & $11,42^{\mathrm{d}}$ & $10,00^{\mathrm{c}}$ \\
\hline 4 ton/ha & $11,28^{\mathrm{d}}$ & $13,72^{\mathrm{c}}$ & $14,70^{\mathrm{b}}$ & $13,24^{\mathrm{b}}$ \\
\hline 6 ton/ha & $13,70^{c}$ & $14,41^{\mathrm{b}}$ & $15,78^{\mathrm{a}}$ & $14,63^{\mathrm{a}}$ \\
\hline Rata-rata & $10,89^{c}$ & $13,01^{\mathrm{b}}$ & $13,97^{\mathrm{a}}$ & \\
\hline
\end{tabular}

Superskrip yang berbeda pada baris dan kolom yang sama serta matriks interaksi menunjukkan perbedaan nyata pada taraf $\alpha=5 \%$

Tabel 4. menunjukkan bahwa penambahan berbagai dosis arang sekam padi dengan pupuk kandang sapi yang meningkat mampu meningkatkan jumlah baris biji jagung. Hal ini menunjukkan arang sekam padi dan pupuk kandang sapi tersebut menyediakan unsur hara makro dalam tanah sehingga apabila unsur tersebut terakumulasi di dalam tanah dan organ tanaman akan meningkatkan pengisian biji sehingga jumlah baris biji jagung meningkat. Proses pembentukkan buah atau biji dipengaruhi oleh terpenuhinya kebutuhan akan unsur silika yang terkandung dalam arang sekam padi dan perbaikan sifat fisik tanah untuk mengontrol keseimbangan pertukaran ion bebas didalam tanah sehingga 
pembentukkan buah tetap berlangsung dengan baik. Distribusi fotosintat yang dihasilkan akan ditransfer dan disimpan dalam biji pada saat pengisian biji serta pengaruh angin kencang saat proses pembuahan berlangsung dapat mempengaruhi pengisian biji pada tongkol jagung yang berasal dari bunga betina. Hal ini sesuai dengan pendapat Dewanto, et al. (2013) bahwa unsur yang diserap oleh tanaman akan dipergunakan untuk pembentukkan protein dan lemak yang akan disimpan dalam biji. Pendapat tersebut sesuai dengan pendapat Polii dan Tumbelaka (2012) yang menyatakan bahwa unsur makro N, P, K terkandung di dalam pupuk organik maupun anorganik dengan peran meningkatkan pertumbuhan tanaman mulai dari pembentukan akar, daun, batang, bunga sampai buah. Indraswari, et al. (2017) menambahkan bahwa gagalnya pembentukkan biji secara alamiah diakibatkan perbedaan masa resesif stigma dengan viabilitas polen, sehingga memberi peluang terhadap gagalnya penyerbukan dan pembuahan yang akhirnya menyebabkan kegagalan pembentukan biji.

Jumlah baris biji jagung pada perlakuan arang sekam padi 6 ton/ha dengan pupuk kandang sapi 15 ton/ha menghasilkan jumlah baris biji 15,78 baris sudah mampu memenuhi potensial genetik dari tanaman jagung hibrida yaitu $12-14$ baris per tongkol (Balitsereal, 2012).

\section{Bobot Pipilan Jagung per Tongkol}

Hasil analisis ragam memperlihatkan bahwa perlakuan arang sekam padi, pupuk kandang sapi dan interaksi antara arang sekam padi dengan pupuk kandang sapi berpengaruh nyata terhadap bobot pipilan jagung. Hasil pengamatan bobot pipilan jagung pada perlakuan pemberian arang sekam padi dan pupuk kandang sapi serta hasil uji jarak berganda disajikan pada Tabel 5.

Tabel 5.

Bobot Pipilan jagung (kg) akibat berbagai dosis arang sekam padi dan pupuk kandang sapi

\begin{tabular}{ccccc}
\hline \hline \multirow{2}{*}{$\begin{array}{c}\text { Dosis Arang Sekam } \\
\text { Padi }\end{array}$} & \multicolumn{3}{c}{ Dosis Pupuk Kandang Sapi } & \multirow{2}{*}{ Rata-rata } \\
\cline { 2 - 3 } & 0 ton/ha & 7,5 ton/ha & 15 ton/ha & \\
\hline & $\ldots$ ton/ha.................(kg).............................. & $0,20^{\mathrm{c}}$ & $0,38^{\mathrm{a}}$ \\
4 ton/ha & $0,13^{\mathrm{d}}$ & $0,21^{\mathrm{c}}$ & $0,43^{\mathrm{b}}$ & $0,36^{\mathrm{a}}$ \\
6 ton/ha & $0,23^{\mathrm{c}}$ & $0,42^{\mathrm{b}}$ & $0,49^{\mathrm{a}}$ & $0,38^{\mathrm{b}}$ \\
\hline Rata-rata & $0,21^{\mathrm{c}}$ & $0,44^{\mathrm{b}}$ & $0,37^{\mathrm{a}}$ & \\
\hline
\end{tabular}

Superskrip yang berbeda pada baris dan kolom yang sama serta matriks interaksi menunjukkan perbedaan nyata pada taraf $\alpha=5 \%$

Tabel 5. menunjukkan bahwa penambahan berbagai dosis arang sekam padi dengan pupuk kandang sapi yang meningkat mampu meningkatkan bobot pipilan jagung dan menghasilkan perbedaan yang nyata. Hal ini menunjukkan unsur yang terkandung dalam arang sekam padi dan pupuk kandang sapi tersebut terakumulasi di dalam tanah salin sehingga dapat menurunkan kadar natrium didalam tanah dan memperbaiki sifat fisik, biologi dan kimia tanah menjadi lebih baik untuk kelangsungan proses pembentukkan biji jagung pada tongkol jagung serta akan meningkatkan bobot pipilan jagung per tongkol. Penggunaan arang sekam padi dan pupuk kandang sapi yang mampu 
menghasilkan unsur hara untuk memperbaiki kondisi tanah menjadi lebih subur dan gembur sehingga tanaman dalam menghasilkan fotosintat untuk membentuk biji meskipun tanaman tumbuh pada kondisi lingkungan yang salin. Pendapat tersebut sesuai dengan pendapat Pranasari, et al. (2012) yang menyatakan bahwa fotosintesis yang dipengaruhi keadaan kekeringan yang disebabkan salinitas dengan tekanan turgor yang menurun menyebabkan stomata tertutup mengakibatkan suplai $\mathrm{CO}_{2}$ untuk fotosintesis berkurang, sehingga laju fotosintesis menurun dan fotosintat berkurang. Arang sekam padi mengandung unsur silika dan hara makro yang terkandung pada pupuk kandang sapi dapat mempertahankan tanaman selama masa pembentukkan biji dari pengaruh lingkungan yang tidak menguntungkan seperti kondisi salinitas tanah. Sesuai dengan pendapat Pasta, et al. (2015) yang menyatakan bahwa unsur makro pada masa generatif berfungsi sebagai sumber energi dalam berbagai reaksi metabolisme tanaman untuk meningkatkan hasil dan memberikan banyak fotosintat yang didistribusikan ke dalam biji sehingga hasil biji tanaman jagung meningkat.

Bobot pipilan jagung pada perlakuan arang sekam padi 6 ton/ha dengan pupuk kandang sapi 15 ton/ha menghasilkan bobot pipilan $0,49 \mathrm{~kg}$, hal tersebut menunjukkan bahwa bobot pipilan jagung yang dihasilkan belum mampu memenuhi potensial genetik dari tanaman jagung hibrida yaitu 13 ton/ha (Balitsereal, 2012).

\section{Rendemen}

Hasil analisis ragam memperlihatkan bahwa perlakuan arang sekam padi, pupuk kandang sapi dan interaksi antara arang sekam padi dengan pupuk kandang sapi berpengaruh nyata terhadap pada persentase rendemen jagung. Hasil pengamatan persentase rendemen jagung pada perlakuan pemberian arang sekam padi dan pupuk kandang sapi serta hasil uji jarak berganda disajikan pada Tabel 6.

Tabel 6. menunjukkan bahwa penambahan berbagai dosis arang sekam padi dengan pupuk kandang sapi yang meningkat mampu meningkatkan persentase rendemen. Hal ini menunjukkan bahwa arang sekam padi dan pupuk kandang sapi tersebut tersedia dalam tanah sehingga mampu menjaga kestabilan pertumbuhan tanaman jagung sampai menghasilkan hasil tanaman meskipun berada pada kondisi lahan yang tidak menguntungkan.

Tabel 6.

Rendemen jagung (\%) akibat berbagai dosis arang sekam padi dan pupuk kandang sapi

\begin{tabular}{|c|c|c|c|c|}
\hline \multirow{2}{*}{$\begin{array}{c}\text { Dosis Arang Sekam } \\
\text { Padi }\end{array}$} & \multicolumn{3}{|c|}{ Dosis Pupuk Kandang Sapi } & \multirow{2}{*}{ Rata-rata } \\
\hline & 0 ton/ha & 7,5 ton/ha & 15 ton/ha & \\
\hline \multicolumn{5}{|c|}{ [............................... (\%) (\%) } \\
\hline 0 ton/ha & $73,33^{f}$ & $91,32^{\mathrm{cd}}$ & $84,79^{\mathrm{e}}$ & $83,15^{\mathrm{b}}$ \\
\hline 4 ton/ha & $91,90^{\mathrm{cd}}$ & $91,97^{\mathrm{c}}$ & $93,07^{\mathrm{bc}}$ & $92,32^{\mathrm{a}}$ \\
\hline 6 ton/ha & $87,81^{\mathrm{de}}$ & $96,44^{\mathrm{ab}}$ & $97,04^{\mathrm{a}}$ & $93,76^{\mathrm{a}}$ \\
\hline Rata-rata & $84,35^{\mathrm{b}}$ & $91,63^{\mathrm{a}}$ & $93,24^{\mathrm{a}}$ & \\
\hline
\end{tabular}

Superskrip yang berbeda pada baris dan kolom yang sama serta matriks interaksi menunjukkan perbedaan nyata pada taraf $\alpha=5 \%$ 
Yaumalika, et al. (2017) menyatakan bahwa pertumbuhan sampai dengan produksi sangat membutuhkan kondisi lahan yang subur untuk meningkatkan metabolisme dari tanaman untuk memproduksi hasil tanaman. Persentase rendemen jagung yang tinggi dipengaruhi oleh unsur fosfor yang terkandung dalam arang sekam padi. Wangiyana, et al. (2010) menambahkan bahwa peningkatan serapan $\mathrm{P}$ dibutuhkan tanaman karena sebagai bahan pembentukan ATP dalam proses respirasi untuk peningkatan proses metabolisme, termasuk fotosintesis terutama selama fase pengisian biji.

Persentase rendemen jagung pada perlakuan arang sekam padi 6 ton/ha dengan pupuk kandang sapi 15 ton/ha menghasilkan 97,04\%, hal tersebut menunjukkan bahwa rendemen jagung yang dihasilkan sudah mampu memenuhi potensial genetik dari tanaman jagung hibrida yaitu $83 \%$ - 93\% (Balitsereal, 2012).

\section{SIMPULAN}

Penelitian menunjukkan pada perlakuan dosis arang sekam padi 6 ton/ha dan pupuk kandang sapi 15 ton/ha menghasilkan pertumbuhan dan produksi lebih tinggi. Tinggi tanaman, jumlah daun, bobot pipilan jagung masih dibawah potensial genetik tanaman jagung hibrida. 


\section{DAFTAR PUSTAKA}

Amiruddin, U. Hasanah dan S. Samudin. Respon pertumbuhan tanaman sorgum (Sorghum bicolor. L.) terhadap tingkat kelengasan dan dosis pupuk kandang sapi yang berbeda. E-J Agrotekbis 5(6): 637645.

Amrullah, D. Sopandie, Sugianta dan A. Junaedi. 2014. Peningkatan produktivitas tanaman padi (Oryza sativa L.) melalui pemberian nano silika. J Tanaman Pangan 13 (1):17-32.

Asroh, A. 2010. Pengaruh takaran pupuk kandang dan interval pemberian pupuk hayati terhadap pertumbuhan dan hasil tanaman jagung manis (Zea mays saccharata Linn). J Agronobis 2(4):1-6.

Balai Penelitian Tanaman Serealia. 2012. http://balitsereal.litbang.pertanian. go.id/. (7 Oktober 2019).

Dewanto, F. G., J. J. M. R. Londok, R. A. V. Tuturoong dan W. B. Kaunang. 2013. Pengaruh pemupukan anorganik dan organik terhadap produksi tanaman jagung sebagai sumber pakan. J Zootek 32(5):1-8.

Kementerian Pertanian Republik Indonesia. 2018. https://www.pertanian. go.id. (7 Oktober 2019).

Mutaqin, Z., H. Saputra dan D. Ahyuni. 2019. Respons pertumbuhan dan produksi jagung manis terhadap pemberian pupuk kalium dan arang sekam. J Planta Simbiosa 1 (1):3950.

Nurahmi, F. 2010. Kandungan unsur hara tanah dan tanaman selada pada tanah bekas tsunami akibat pemberian pupuk organik dan anorganik. J Floratek 5(1):74-85.

Onggo, T. M. Kusmiyati dan A. Nurfitriana. 2017. Pengaruh pe-nambahan arang sekam dan ukuran polybag terhadap pertumbuhan dan hasil tanaman tomat kultivar valouro hasil sambung batang. J Kultivasi 16 (1):298-304.

Pasta, I., A. Ette dan H. N. Barus. 2015. Tanggap pertumbuhan dan hasil tanaman jagung manis (Zea mays L. Saccharata) pada aplikasi berbagai pupuk organik. E-J Agrotekbis 3 (2):168-177.

Pikukuh, P., Djajadi, S. Y. Tyasmoro dan N. Aini. 2015. Pengaruh frekuensi dan konsentrasi penyemprotan pupuk nano silika (Si) terhadap pertumbuhan tanaman tebu (Saccharum officinarum L.). J Produksi Tanaman 3(3):249-258.

Purwaningsih, D. 2009. Adsorpsi multi logam $\mathrm{Ag}(\mathrm{I}), \mathrm{Pb}(\mathrm{II}), \mathrm{Cr}(\mathrm{III}), \mathrm{Cu}(\mathrm{II})$ dan $\mathrm{Ni}(\mathrm{II})$ pada hibrida etilendiaminosilika dari abu sekam padi. J Penelitian Saintek 14(1):59-76.

Subowo, G. 2010. Strategi efisiensi penggunaan bahan organik untuk kesuburan dan produktivitas tanah melalui pemberdayaan sumberdaya hayati tanah. J Sumberdaya Lahan 4 (1):13-25.

Wangiyana, W., M. Hanan dan I. K. Ngawit. 2010. Peningkatan hasil jagung hibrida Var. BISI-2 dengan aplikasi pupuk kandang sapi dan peningkatan frekuensi pemberian urea dan campuran SP-36 dan $\mathrm{KCl}$. J Ilmiah Budidaya Pertanian 3(1): 51-58.

Zulputra, Wawan dan Nelvia. 2014. Respon padi gogo (Oryza sativa L.) terhadap pemberian silikat dan pupuk fosfat pada tanah ultisol. J Agroteknologi 4(2):1-10.

Muharam. 2017. Efektivitas penggunaan pupuk kandang dan pupuk organik cair dalam meningkatkan pertumbuhan dan hasil tanaman kedelai (Glycine Max L.) varietas Anjasmoro di tanah salin. J Agrotek Indonesia 2(1):44-53. 